The AAPS Journal 2006; 8 (3) Article 70 (http://www.aapsj.org).

Themed Issue: Drug Addiction - From Basic Research to Therapies

Guest Editors - Rao Rapaka and Wolfgang Sadée

\title{
Corrigendum: Current Status of Immunologic Approaches to Treating Tobacco Dependence: Vaccines and Nicotine-specific Antibodies
}

Submitted: March 8, 2006; Accepted: July 18, 2006; Published: September 29, 2006

Mark G. LeSage, Daniel E. Keyler, and Paul R. Pentel

AAPS Journal. 2006;8(1):E65-E75. DOI: 10.1208/aapsj080108

In the section "Studies in Humans," subsection "Potential Efficacy," second paragraph, the phrase "(a tobacco carcinogen nicotine metabolite)" should have read "(a tobacco carcinogen metabolite)." 